PETER SIMONS

Trinity College Dublin

psimons@tcd.ie

\title{
CONFLUENCE: THE GALICIAN ORIGINS OF POLISH ANALYTIC PHILOSOPHY
}

\begin{abstract}
Separate Austrian influences, those of Bolzano and Brentano, came together in the work of Kazimierz Twardowski, the founder of the Lvov-Warsaw School and Polish analytic philosophy. From Bolzano he took the ideas of abstract content and absolute truth; from Brentano the centrality of intentionality and the role of psychology, and from both an awareness of the historical depth of philosophy. These streams flowed together in and through him to form central doctrines, attitudes and practices of that School, from its origins in 1895 to its continuation in contemporary Polish philosophy.
\end{abstract}

Keywords. Polish analytic philosophy, content, object, idea, intentionality, truth, absolute truth.

\section{Prelude: The Geopolitics of Central - Eastern Europe}

Near the Polish city of Mysłowice, south-east of Katowice in Silesia, two small rivers flow together: the Black Przemsza from the north-west, and the White Przemsza from the north-east, forming the Przemsza, a short tributary of Poland's main river, the Vistula. The confluence of the two tributaries of the Przemsza was, from 1871 to 1914, a geopolitical tripoint, where three empires met: the German Empire to the west, the Russian Empire to the north, and the Austro-Hungarian empire to the east, and it became known as Three Emperors' Corner, Dreikaisereck, Trójkąt Trzech Cesarzy, Уголтрёхимператоров. I am using the flowing together, or confluence, of streams of water to form a new stream as a metaphor for the bringing together of two streams of thought to form a new stream, combining aspects of the two. The Dreikaisereck represents three of the polities figuring in my story: Germany, Austria, and Poland. I shall be talking about three philosophers: the German Franz Brentano, the Austrian, (Bohemian) Bernard Bolzano, and the Pole, Kazimierz Twardowski. Twardowski's is the mind bringing together the influences of Bolzano and Brentano and originating a new and powerful stream of Polish thought, which flowed metaphorically into the Vistula in Warsaw and became one of the chief 
intellectual movements of the inter-war period, a veritable Golden Age of Polish science and letters: the Lvov-Warsaw School.

The story begins in 1866, in Vienna, where Kazimierz Twardowski was born to Polish parents. He attended Vienna University where he studied philosophy with Franz Brentano and Robert Zimmermann. In 1891 he obtained his doctorate with a dissertation Idea and Perception in Descartes. His breakthrough work was his 1894 Habilitation dissertation Zur Lehre vom Inhalt und Gegenstand der Vorstellungen, On the Theory of the Content and Object of Presentations (hereafter: $I G V) .{ }^{1}$ On the strength of this work, he was appointed as associate professor (professor extraordinarius) at the University of Lwów (German: Lemberg), then in the Austrian province of Galicia, later in the second Republic of Poland, from 1945 to 1991 in the Soviet Union, and now as L'viv the chief city of western Ukraine. Twardowski's appointment was internal to the AustroHungarian Empire: when Poland regained her independence, his citizenship and employment changed with it, and he taught in Lwów almost until his death in 1938.

Under the relatively mild conditions of Austrian occupation, instruction in the two ancient Polish universities at Kraków and Lwów was in Polish. This contrasted with the extreme suppression of Polish culture in the German and Russian parts of the former Kingdom of Poland. So it was that Austrian influences could pass easily into Polish thought and form the basis for the Polish intellectual explosion of the interwar years. Lwów was the younger of the two universities, founded in 1661 by King Jan II Kazimierz, whose name it bore from 1919-1939.

\section{Vienna, Brentano, Zimmermann}

Twardowski's philosophical mentors in Vienna were Robert Zimmermann (1824-1898) and Franz Brentano (1838-1917). The latter is by far the better known so we start with him.

Franz Brentano came from the German Rhineland and studied and then taught in Germany, but from 1874-1895 he taught philosophy at the University of Vienna, inspiring a superbly talented array of students including Tomáš Garrigue Masaryk, Alexius Meinong, Edmund Husserl, Christian von Ehrenfels, Sigmund Freud and others. His lectures on ethics were famous and attracted huge numbers of students. More famous still was the scandal of Brentano's loss of his professorship. In 1880 he had married the daughter of a Jewish banker, an act

\footnotetext{
${ }^{1}$ TWARDOWSKI [1894].
} 
which for him as a former priest was thought by some to be against Austrian law. To safeguard against possible legal proceedings, Brentano had resigned his professorship and married in Saxony. The expected reinstatement to his chair never came about, as his action had displeased the conservative Emperor Franz Josef, so from 1880-1895 he taught in Vienna as a mere unsalaried Privatdozent, unable to supervise dissertations. So it came about that Twardowski, while strongly influenced by Brentano's messianic vision of a new scientific rigorous philosophy based on psychology, had Brentano's senior colleague Zimmermann as supervisor.

Robert Zimmermann came from Prague. As a young boy, he had been a particular favourite of his father's friend Bernard Bolzano (1781-1848), the greatest of $19^{\text {th }}$ century philosophers. Bolzano, who himself had suffered the loss of both his Prague chair and his priestly offices through the reactionary actions of church and state in Metternich's Austria, was particularly concerned to find someone able to appreciate and pass on his revolutionary views in logic and mathematics, and he adopted the young Robert as his intellectual heir, entrusting him with the manuscript of his incomplete final work on the foundations of mathematics, the Grössenlehre. Unfortunately for Bolzano, Zimmermann was more interested in philosophy than in mathematics, and more unfortunately still, he soon lost sympathy for Bolzano's rigorous logical platonism and preferred the lesser philosophy of Johann Friedrich Herbart. As a result, he did nothing with Bolzano's papers until 1882 when he simply gave them to the Austrian Academy of Sciences. This inaction resulted in a further generation's delay in the reception of Bolzano's work, which only gradually came to the interest of a small coterie of philosophers, including Alois Höfler in Vienna and Edmund Husserl in Germany, in the 1890s. In 1853 Zimmermann had published a textbook of logic and philosophy for secondary school children, ${ }^{2}$ based on the ideas of Bolzano's great Wissenschaftslehre, but without attribution (this was with Bolzano's approval). But a second edition of 1860 replaced Bolzano's clear ideas by Herbart's less clear ones, and that was almost the end of Bolzano's influence for more than thirty years.

However, as supervisor of Twardowski, it is very likely that Zimmermann told Twardowski about Bolzano's theory of ideas and propositions in themselves. Another possible source of Twardowski's acquaintance with Bolzano's thought was Alois Höfler, teaching in Vienna and interested in Bolzano. Certainly nowhere else in the world was as cognizant of Bolzano as the philosophy department in 1890s Vienna, so it was fortunate for posterity and for Polish thought that Twardowski studied there.

\footnotetext{
${ }^{2}$ ZIMMERMANN [1853].
} 


\section{Intentionality}

Brentano's rightly most famous contribution to philosophy was his reintroduction, in his opus magnum Psychology from an Empirical Standpoint ${ }^{3}$, of the ancient and medieval doctrine of the intentional inexistence of objects of consciousness. The Psychology, which secured Brentano's professorship in Vienna, but whose first publication contained only two out of six projected parts ("books"), developed out of Brentano's study of Aristotle and the Scholastics, but also of the British empiricists and their founding of philosophy on the theory of the human mind. Brentano sought a criterion for distinguishing the subject matter of the mental science of psychology from the physical sciences, since he denied the then popular view that psychology was reducible to physiology. Method alone could not distinguish one science from another, since Brentano held that, with the exception of the a priori science of mathematics, all sciences, including philosophy, share the same method. Therefore, if psychology was to be an autonomous science, it had to be distinguished by its subject matter, what Brentano called mental phenomena.

Among several contenders for a distinguishing mark of mental phenomena as distinct from physical phenomena, Brentano selected what he called intentional inexistence. An idea, a judgement, an emotion, a desire, are all of something: they have what we can call "aboutness". I see a tree, I judge that its leaves are green, I like the flowers under the tree, and I want to lie down in its shade. By contrast, the tree, the leaves, the flowers, the shade, have no "aboutness": they are not of anything; they just are. So they are physical phenomena, while my idea, judgement etc. are mental phenomena. All mental phenomena have this aboutness or of-ness, no physical phenomenon has.

This feature is present in Aristotle's theory of perception in De Anima: when I perceive a tree, the form of Tree is present in my soul, but minus the matter that helps to make a real tree. Because of the general mistrust of metaphysics at this time, Brentano prefers to speak not of the soul but of mental acts, and influenced by Descartes and Comte, he prefers not to commit himself to the existence of an independent physical reality. The aboutness of a mental act is therefore modelled on the relation of whole to part. The object of a mental act is immanent in or part of the act itself. So the tree-I-see is not an external physical thing but a part of my seeing. This justifies the term 'inexistence': the tree-I-see exists as a physical phenomenon in the seeing of the tree as a mental phenomenon. Discussion of the several varieties of this inexistence are what forms the bulk of Brentano's Psychology.

\footnotetext{
${ }^{3}$ BRENTANO [1874].
} 
The nature of inexistence led Brentano to use as near-synonyms several different terms for that which a mental act is about: object, content, immanent objectivity. Brentano's defence of the autonomy of psychology and his selection of intentionality as the mark of its subject matter were to influence both empirical psychology and phenomenology. But the instability and potential scepticism of the inexistence doctrine led to dissatisfaction among Brentano's students. In 1890, Höfler and Meinong published a school logic and psychology textbook ${ }^{4}$ (replacing that of Zimmermann) in which they distinguished between an immanent or mental object on the one hand, and an external object on the other. This distinction and its terminological anchoring was to be the subject of $I G V$, Twardowski's Habilitationsschrift.

\section{Ideas}

In German, the standard term for the Cartesian - Lockean concept of idea is Vorstellung. The term Idee does occur, but less often (Twardowski used it in his dissertation on Descartes.) The word Vorstellung was introduced into German philosophical terminology by Christian Wolff as the German equivalent of the Latin words idea and repraesentatio. ${ }^{5}$ It is a regular German word with many meanings, it comes from the idea of putting (stellen) something before (vor) something or somebody. Generally, it was used where philosophers writing in Latin, French or English would use 'idea' or 'idée'. It has the disadvantage of being long, and of being variously translatable, giving rise to a rather pointless discussion in English translations of Kant, Schopenhauer and other Germans about whether 'idea', 'presentation' or 'representation' is the best rendering. On the other hand, it comes from a verb '(sich etwas) vorstellen', so that the verbs 'present' and 'represent' can be used, whereas the verb 'ideate' is extremely unnatural and can also have other meanings. I use 'present' for vorstellen, the verb, and 'idea' for Vorstellung, the noun.

\section{Content and Object of Ideas}

Twardowski's little book on the content and object of ideas was and is a classic. It is barely a hundred pages long, yet with a clarity and succinctness practically unknown in German-language philosophy it made the case for a clear distinction between an immanent, mental aspect of presenting, and a transcendent target of the presenting. The former Twardowski called Inhalt, the 'content', the latter

\footnotetext{
${ }^{4}$ HÖFLER and MEINONG [1890].

${ }^{5}$ KNÜPFER [1911], p. 14.
} 
Gegenstand, the 'object', of the idea. Twardowski thus exploited the terminological redundancy in Brentano to anchor the distinction. The book had immediate influence on others of Brentano's former students, in particular Meinong and Husserl, who went on to develop their own (differing) versions of the content-object distinction.

The arguments Twardowski uses to make the distinction are easy to summarize. They come in Section 6. If I think of something that does not exist, such as the god Zeus, then while Zeus does not exist, the content representing him does. So they cannot be the same. Content and object cannot be the same because they often have different properties and stand in different relations. The number 4 is divisible by 2 , but the content presenting the number 4 is not divisible by any number. A mountain is extended and rocky, but the content presenting it is neither. Finally, different contents may present the same object. The content the city on the site of the Roman Juvavum is a different content from the birthplace of Mozart, but both present the same object, Salzburg. Such examples and arguments are commonplace today, though they are more often recounted in connection with Frege's distinction between the sense and reference of expressions. Twardowski's psychological distinction is indeed closely analogous to Frege's linguistic one.

\section{Two Kinds of Content}

When he introduces the content/object distinction, Twardowski quotes Höfler with approval, where it is stated:

What we call 'the content of an idea and a judgement' lies just as completely within the subject as the act of presenting or judging itself. ${ }^{6}$

This makes the content of an idea something mental, and therewith something in time, if not (according to views then prevalent) in space. For this reason, I can think of something that does not exist at the same time as my thinking of it, or does not exist in space and time, or does not exist at all, but all the contents are in time and can be given a date. This conception of content as something immanent and mental is in accord with Brentano, and is the view adopted later by Meinong.

A little later in his monograph, however, Twardowski talks about naming and meaning. He notes that names and ideas are closely correlated with one another. When we name something, he says, we do three things: we indicate or express that we are presenting something; we intend to arouse in listeners a presentation with the same content; and we name, designate or refer to something. When I

${ }^{6}$ TWARDOWSKI [1894], p. 4; HÖFLER and MEINONG [1890], § 6. 
said 'the same content', this can be understood in two different ways. Someone other than myself cannot have the same content if we are two different people and 'content' refers to something mental, since my content and theirs have to be distinct. In that case, what 'the same' means must be something like 'the same in kind' or 'similar'. On the other hand, if 'the same' means 'identical' then my content and someone else's can be the same, but then content cannot be something mental, but must be something abstract, which two or more people can share in common. Twardowski's use of 'the same content' in connection with naming in fact tends rather to support this second reading, of content as something abstract, since he equates the content I and my hearer have in mind when I use a name with the name's meaning, and that is something abstract: "This content is that which is understood by the "meaning" (Bedeutung) of a name." 7

This uncertainty in the status of content (mental versus abstract) is I think not accidental: it derives from Twardowski's two principal sources: Brentano and Bolzano.

\section{Bolzano on Ideas}

In $I G V$, two philosophers are mentioned more often than any others, and each is mentioned as often as the other. They are Brentano and Bolzano. The frequency of mentions of Brentano is unsurprising, since he taught and influenced Twardowski directly. That of Bolzano is more surprising. We already mentioned the likely sources, namely Zimmermann and Höfler. But Twardowski does not just refer to Bolzano, he employs (and criticises) his philosophy. Section 5 of Twardowski's work is entitled "So-called 'objectless' ideas." He quotes Bolzano's Wissenschaftslehre, ${ }^{8}$ where Bolzano upholds the claim that there are ideas which have no objects. As examples, Bolzano gives 'nothing', 'round square', 'green virtue' and 'golden mountain'. Students of Meinong will recognize some of these as familiar. Twardowski rightly objects against Bolzano that 'nothing' is a syncategorematic term, not in the business of presenting objects, but against the other three cases he argues quite fallaciously that Bolzano confuses not having an object with not being presented. Indeed, one of Twardowski's chief theses in $I G V$ is that all ideas have objects, even in those cases where the object does not exist. This was the view taken up and made famous, indeed notorious, by Meinong.

Twardowski's acceptance of non-existent objects is not germane to our point, however. What is important for us here is rather that he quotes Bolzano's

\footnotetext{
${ }^{7}$ TWARDOWSKI [1894], p. 11.

${ }^{8}$ BOLZANO [1837].
} 
Wissenschaftslehre at a time when no one else was doing so. Indeed, he notes with approval in Section 4 that Bolzano makes and maintains a clear distinction between the content of an idea, what he (Bolzano) calls 'objective idea' or 'idea in itself' (Vorstellung an sich) and the object or objects (if any) of the idea. Bolzano's robust platonist theory of ideas and propositions in themselves (Sätze an sich) is indeed the first feature of his logic reform that catches one's attention. It is insisted upon by him as the key that unlocks the whole panoply of rigorous logical conceptions. Bolzano distinguishes, in particular, between ideas as something mental, subjective ideas, and ideas in themselves, or objective ideas, and he calls the objective ideas the contents of subjective ideas and the meanings of linguistic terms. As a logician, Bolzano dwells far less than does Twardowski on the subjective or mental aspect, but the relationship is exactly as Twardowski says. Bolzano, like Frege after him, speaks of the individual subject grasping (erfassen) objective ideas and propositions. So to the extent that Twardowski is using Bolzano's conception of ideas in themselves as contents, he is using the abstract rather than the mental concept of content. In the context of his approval of Bolzano, Twardowski also approvingly quotes Zimmermann, who likewise emphasizes the distinction, and in addition the much younger Benno Kerry, another Brentano student from Vienna whose work on logic and mathematics famously came to the attention of Frege. The juxtaposition of the quotes from Bolzano and Zimmermann makes it plausible that it was Zimmermann who brought Bolzano's discussion to Twardowski's attention.

The first and perhaps most important way in which the initially very distinct streams of thought on ideas, coming from Brentano on the one hand, and Bolzano on the other, flow together is in the work of Twardowski on the content of ideas. The ambiguity or indecision of Twardowski's conception as to whether contents are mental or abstract can indeed be taken as an implicit mark of the divergent origins of his conception. Of course, it is perfectly possible to reconcile the two conceptions, as Husserl was to do a little later in his Logical Investigations, by saying that an abstract content is the ideal type or species of which the mental contents are instances.

\section{Truth}

In his middle years, Brentano held to a somewhat tentative correspondence theory of truth, though he later repudiated it in favour of an evidence theory. Bolzano, on the other hand, had a very straightforward and, indeed, rather deflationary conception of truth. A proposition (henceforth I drop the 'in itself') of the form $A$ has $b$ is true if and only if every object falling under the subject 
term $A$ has some attribute falling under the predicate term $b .{ }^{9}$ For example, the proposition [Snow is white], in its canonical form [Snow has whiteness], is true if and only if every batch of snow has some type of whiteness. This is, appearances to the contrary, a general definition of truth, since Bolzano held that all propositions, no matter how expressed linguistically, can be put into an equivalent subject-predicate form $A$ has $b$, where $A$ is any term and $b$ is a term denoting an abstract attribute. It is clear from Bolzano's account that no proposition is true at one time and false at another: propositions are out of time and so are either true, period, or false, period. If a form of words, such as 'Socrates is sitting' or 'I am tired', expresses something true at one time and something false at another, then the different occurrences of the form of words in question express different propositions.

The idea that truth is thus absolute, and not relative to time, place, speaker or other circumstance, is one which Twardowski upheld and defended vigorously in a paper of 1900 with the title 'O tzw. prawdach względnych', 'On so-called relative truths', translated into German in 1902 as 'Über sogenannte relative Wahrheiten'. ${ }^{10}$ In the paper, Twardowski upheld the view, consonant with that of Bolzano, and perhaps even inspired by him, that appearances to the effect that a proposition could change its truth value stemmed from elliptical uses of language, in which aspects of the circumstances of utterance of a sentence are exploited to make it unnecessary in the context pedantically to spell out all the features that would pin down a unique proposition as the meaning of the sentence. ${ }^{11}$ The importance of Twardowski's defence of absolute truth, then almost certainly a minority view, for the subsequent development of philosophy and logic in Poland, is considerable. ${ }^{12}$

\section{The Lwów School, 1895-1939}

On arriving in the Polish-speaking University of Lwów in 1895, Twardowski found Polish philosophy in a lamentably backward state by comparison with that of Vienna, then at the forefront of philosophical developments. He therefore set about transforming philosophical life, by his teaching, by reforms of the way in which philosophy was examined, and by the professional institutions supporting philosophy. He was tirelessly energetic in introducing and implementing these reforms, all of which were aimed at improving the standards of philosophy in his part of Polish-speaking Europe. The price he paid for this organisatory and reforming activity was that his own aspirations to be a researcher in philosophy,

\footnotetext{
${ }^{9}$ BOLZANO [1935], p. 90.

${ }^{10}$ TWARDOWSKI [1900].

${ }^{11}$ See SIMONS [2009].

${ }^{12}$ See WOLEŃSKI and SIMONS 1989.
} 
publishing books and papers and gaining international recognition, had to be drastically curtailed. His energies went into producing the next generation of philosophers writing in Polish rather than into a large philosophical output of his own. His lectures, on the model of his teacher Brentano, were extremely clear and likewise extremely popular. Like his older colleague Meinong, whose advice he sought on the matter, he set up a laboratory of experimental psychology, and trained two generations of Polish psychologists. His rewards were not wide personal fame, of which he was certainly capable, but rather the satisfaction over the next four decades of seeing an immeasurable improvement in standards, and his own students coming to occupy a significant proportion of the chairs of Philosophy and Psychology in the independent Poland of 1919-39. Another achievement, for which Twardowski's own views as well as the generally liberal and progressive environment of Polish intellectual life were jointly responsible, was that a significant number of his students and pupils were female. Twardowski's advanced seminars contained in some cases a majority of women, at a time when female emancipation was making slower progress elsewhere. ${ }^{13}$

In the course of time, Twardowski attracted the brightest and best minds from all parts of the Polish-speaking world to study with him in Lwów. The first to make an independent name for himself was Jan Lukasiewicz, himself a native of the city, whose interests were in the methodology of science, logic, and the history of philosophy. Twardowski and Łukasiewicz indeed jointly translated David Hume's first Enquiry into Polish. The first lectures Twardowski gave in Lwów were on the reforms being made in elementary logic, a topic taking some ideas from Brentano but also looking at developments in Britain and France. Lukasiewicz took up this line of thought and very quickly advanced beyond Twardowski's rather rudimentary skills in logic. Łukasiewicz read and commented on Aristotle as well as Jevons, but he also read Bolzano, Frege and Russell, and visited Meinong in Graz, at a time when both were working on the logic of probability. Lukasiewicz's 1910 mongraph On the Principle of Contradiction in Aristotle was already questioning the orthodoxy of entrenched logical principles, and this questioning attitude came to fruition during the Great War when Łukasiewicz, newly appointed to the reopened University of Warsaw, developed his most significant idea, that of many-valued logic. It was Łukasiewicz who brought the Lwów School into closer appreciation of the logical ideas of Frege, Russell, Couturat and Peirce. But Łukasiewicz also knew his Bolzano. His 1913 monograph on the logical foundations of probability theory, written and published in German, compared his own logical theory of probability with similar ideas of Bolzano. Łukasiewicz's clarity of style surpassed even that of his teacher, as indeed that of all other Polish philosophers

${ }^{13}$ SIMONS [forthcoming]. 
and logicians. Though under the influence of Frege and Husserl he came to reject any admixture of psychology in logic, and replaced psychological terms such as sad, judgement, and przedstawienie, idea, by linguistic ones such as zdanie, sentence, and nazwa, name, Łukasiewicz always remained respectful towards Twardowski.

Soon other talented students came to Lwów to study with Twardowski, among them Władysław Tatarkiewicz, Kazimierz Ajdukiewicz, Tadeusz Kotarbiński, Tadeusz Czeżowski, Wladysław Witwicki, Roman Ingarden and Stanisław Leśniewski. Before the Great War they already formed a circle who discussed and published their ideas in Polish and who interacted with their teacher and amongst themselves. Leśniewski, Czeżowski and Ajdukiewicz were interested in logical problems; Ajdukiewicz and Kotarbiński in general philosophy and methodology, Tatarkiewicz in aesthetics and the history of philosophy, Ingarden in phenomenology and ontology, and Witwicki in psychology. When Poland regained her independence they spread out and populated her new or newly reopened universities in Warsaw, Vilnius and Kraków. Twardowski continued to teach in Lwów, and while his later students such as Leopold Blaustein, Daniela Gromska and Izydora Dąmbska did not attain the international standing of the earlier generation, they continued the high standards of their predecessors.

\section{The New Centre of Gravity: Warsaw}

When Łukasiewicz and then Leśniewski were both appointed Professors at Warsaw University after the Great War, that city and university could boast two more professors of mathematical logic than anywhere else on the planet. They were soon joined by a once-in-a-generation genius, Alfred Tarski (né Tajtelbaum), who studied mathematics as well as philosophy and went on to become the most prominent of Polish logicians. These three between them raised a generation of outstanding logical talent, the concentration of which has never been seen before or since. Twardowski was somewhat dismayed by their obsession with logical detail at the expense of sound common sense, but remained on relatively cordial terms with all of them, except perhaps Leśniewski, whose idiosyncratic and intolerant character led to his eventually falling out with everyone except his close friend Kotarbiński.

The 1920s were a period of establishment and consolidation of the new logical approach to philosophy, the writing of Polish textbooks and the anchoring of new institutions, for which the pre-existing Austrian universities in Lwów and Kraków served as a clear basis. The 1930s saw the newly self-confident Poles reaching out to cognate movements of scientific philosophy in Austria (the Vienna Circle), Germany (the Berlin Group), Britain, France, Scandinavia and 
Czechoslovakia. International congresses and exchanges with such rising talents as Kurt Gödel, Rudolf Carnap, W. V. Quine and Karl Popper, as well as loose participation in the Unity of Science movement, brought Polish philosophy and logic into the mainstream of European analytic thought. Łukasiewicz found a kindred spirit in the first German professor of mathematical logic, Heinrich Scholz, and indeed fled Poland to Münster and Scholz during World War II. It was Scholz, a trained historian of philosophy, who first pointed out the striking similarity between Tarski's 1936 definition of logical consequence and the definition of logische Ableitbarkeit given by Bolzano in 1837. Tarski's own attendance at a Unity of Science meeting at Harvard in 1939 literally saved his life, as he would almost certainly have ended his days in a Nazi death camp, as did most of his Jewish compatriots. Tarski's friend and collaborator Adolf Lindenbaum, and his wife Janina Hosiasson (original author of the Raven Paradox of confirmation ${ }^{14}$ ) did indeed meet such a fate in 1942. In the unstable atmosphere of Summer 1939, Hosiasson had failed, by only days, to obtain a visa to depart on the same ship as Tarski to the USA.

The emphasis on logic in Warsaw was driven in part by the interests of the main actors there, but also in part by the rare collaboration with the Warsaw mathematicians, who understood that it was necessary to specialize in new subjects such as logic, set theory and topology, in order to avoid competing with the established mathematical nations of Germany, France and Britain in areas such as analysis and algebra. The result was to bring Polish philosophy somewhat closer to its Bohemian roots in Bolzano, whose combination of mathematical and philosophical talents was echoed among the Poles. The obsession with truth that had characterized Polish thinking before World War I continued, with essays by Ajdukiewicz, Kotarbiński and Łukasiewicz feeding into the supreme achievement in this genre, Tarski's 1933 monograph The Concept of Truth in the Languages of the Deductive Sciences, translated into German in 1935 by Leopold Blaustein. ${ }^{15}$ Tarski's paper, technically masterful despite its limited philosophical scope, embodied Twardowski's conception of absolute truth in a new mathematically formulated way, continuing the influence of Twardowski's student and Tarski's teacher Leśniewski. Among the logicians, the only one to move slightly away Twardowski's notion of absolute truth was Łukasiewicz, whose three-valued logic envisaged propositions dealing with the future either changing their truth value from merely possible to true or false, depending on what contingently happened, or else being intrinsically tensed.

\footnotetext{
${ }^{14}$ HOSIASSON-LINDENBAUM, J. [1940].

${ }^{15}$ TARSKI [1933]. We now know, following investigation by Jan Woleński, that Twardowski materially assisted Tarski in getting Blaustein as translator, advising on the translation, and in smoothing the way to publication in German.
} 
While the pre-eminence of Warsaw between the wars led to a restrained rivalry with the source in Lwów, and Twardowski no doubt felt himself somewhat upstaged by his younger colleagues, the flow of talent from those two centres continued and spread to other universities. Twardowski's greater emphasis on psychology led to his having a similar dominating influence on Polish psychology to that which he had exercised on Polish philosophy. He never completely gave up his view that psychology has a prominent role for philosophy, though his later writings also recognise the importance of logical and linguistic considerations, as indeed they had from the start.

\section{The Virtues of Polish Analytic Philosophy}

While they never subscribed to the label 'analytic' - there was no need to do so as they had no serious rivals from whom to distinguish themselves - Polish philosophers of the Lvov-Warsaw School were closest in spirit to the broad movement we now know as 'analytic philosophy', whose origins, whether in Prague, Jena or Cambridge, produced work with which theirs could compete on equal and similar terms. The historical Bildung of the school's founder was transmitted to the students, so that while, under the influence of Brentano and later of Frege and Russell, it was felt that Polish philosophy and logic were solidly scientific, modern and innovative, there was never any ignorant supposition that they had no intellectual predecessors, nor that they were launching an unprecedented "revolution in philosophy", a fancy which on occasion gripped Austrian and British philosophers alike. They eschewed the Vienna Circle's extreme and self-undermining critique of metaphysics, they never succumbed to French conventionalism or relativism, and they were never tempted by anything like ordinary language philosophy. Above all, they were epistemological realists and scientific optimists, even or perhaps especially those, such as Ajdukiewicz and Ingarden, who had encountered modern transcendental idealism in Husserl. Having their sources in two Austrian figures, one Bohemian, the other German in origin, both of whom were decidedly 'antiKantian', Polish philosophy was never in danger of succumbing to transcendental - or any other kind of - idealism. To employ the bon mot of the Vienna Circle's arch-historian, Otto Neurath, like Austrian philosophy in general, Polish philosophy was spared the Kantian interlude.

In addition to its doctrinal fortune, Polish philosophy has been blessed - again by and following the example of its founder - with the virtue of expressive clarity. There is rarely any doubt as to what a Polish philosopher means. There is no striving for verbal brilliance or literary effect for its own sake, even though Polish philosophers can be eloquent and pointed in their writings. These virtues, and the intellectual solidity of its surviving members, enabled Polish 
philosophers to shrug off the challenge of Marxism-Leninism in post-Yalta Poland more quickly than in any other of the Soviet satellites.

Polish philosophy today still flourishes. It has its own emphases, which continue those of the pre-war years, and it is rightly proud of its own past. It now fits seamlessly into the general analytic movement, and indeed serves as a welcome counterbalance to some of that movement's more extreme excursions, whether into modal realism, monism, mereological nihilism, alethic relativism, Carnapian methodological insouciance or neo-Hegelian coherentist epistemology. This moderating influence echoes that of its interwar years.

Where the Black and the White Przemsza rivers flow together, three Empires once stood. Now that minor confluence is internal to the Republic of Poland, and its historical significance almost forgotten. The streams of thought of Bolzano and Brentano are not minor, indeed they represent perhaps the two most scientifically significant systems of philosophy in the $19^{\text {th }}$ century (which is not to say they are the most influential!) Their confluence in the thought of Twardowski, who for influence rivals Brentano, and whose career as a leader in philosophy started in Austrian Galicia, is highly significant. Twardowski's judicious mixture of logical, ontological, psychological and historical considerations not only provided a firm and fertile basis for the development of a whole nation's philosophy, but also, in my opinion, got the balance right as to how philosophy should properly be done.

\section{References}

BOLZANO, B. [1837], Wissenschaftslehre. Versuch einer ausführlichen und grösstentheils neuen Darstellung der Logik mit steter Rücksicht auf deren bisherige Bearbeiter. 4 vols. Sulzbach: Seidel. Repr. Aalen: Scientia, 1981. Eng. transl. Theory of Science. Oxford: Oxford University Press, 2014.

BOLZANO, B. [1935], Der Briefwechsel B. Bolzano's mit F. Exner, E. Winter (ed.), Prague: Royal Bohemian Society of Sciences.

BRENTANO, F. [1874], Psychologie vom empirischen Standpunkte. Leipzig: Duncker \& Humblot. $2^{\text {nd }}$ (ed.), Leipzig: Meiner, 1924. Eng. transl. Psychology from an Empirical Standpoint. London: Routledge \& Kegan Paul, 1973.

HOSIASSON-LINDENBAUM, J. [1940], On Confirmation. The Journal Of Symbolic Logic 5, 133-148.

HÖFLER, A. and MEINONG, A. [1890], Philosophische Propädeutik - I Theil: Logik. Prague/Vienna/Leipzig: Tempsky/Freytag.

KNÜPFER, C. [1911], Grundzüge der Geschichte des Begriffs 'Vorstellung' von Wolff bis Kant. Halle/S, $2^{\text {nd }}$ (ed.) Repr. Hildesheim: Olms, 1999. 
SIMONS, P. [2009], Twardowski on Truth. The Baltic International Yearbook of Cognition, Logic and Communication 4: 200 Years of Analytical Philosophy, 2009, 1-14.

SIMONS, P. [forthcoming], Logical Philosophy, Anti-Irrationalism, and Gender Equality: Three Positives of the Lvov-Warsaw Enlightenment. In Brożek, A. (ed.), The Significance of the LvovWarsaw School in European Culture. Leiden: Brill.

TARSKI, A. [1933], Pojęcie prawdy w językach nauk dedukcyjnych. Prace Towarzystwa Naukowego Warszawskiego, Wydział III. Nauk Matematyczno-Fizycznych, nr 34, Warsaw. Repr. [in:] TARSKI [1995], pp. 13-172. English translation: The Concept of Truth in Formalized Languages, [in:] TARSKI [1956], 152-278.

TARSKI, A. [1956], Logic, Semantics, Metamathematics. Oxford: Clarendon Press. 2nd ed. Indianapolis: Hackett.

TARSKI, A. [1995], Pisma logiczno-filozoficzne. Tom 1: Prawda. Warsaw: PWN.

TWARDOWSKI, K. [1894], Zur Lehre vom Inhalt und Gegenstand der Vorstellungen, Eine psychologische Untersuchung. Vienna: Hölder. Repr. Munich: Philosophia, 1982. Eng. transl. On the Content and Object of Presentations. The Hague: Nijhoff, 1977.

TWARDOWSKI, K. [1900], O tak zwanych prawdach względnych. Księga Pamiatkowa Uniwersytetu Lwowskiego ku uczczeniu pięćsetnej rocznicy fundacji Jagiellońskiej Uniwersytetu Krakowskiego. Lwów, nakładem Senatu Akademickiego Uniwersytetu lwowskiego. Repr. In TWARDOWSKI [1965], pp. 315-336; modified German transl. Über so genannte relative Wahrheiten, Archiv für systematische Philosophie, 8, (1902), 415-447; repr. in Pearce, D. and Woleński, J. (eds), Logischer Rationalismus. Ausgewählte Schriften der Lemberg-Warschauer Schule, Frankfurt: Athenäum, 1988, pp. 38-58. Engl. transl. On so called Relative Truths in TWARDOWSKI [1999], pp. 147-169.

TWARDOWSKI, K. [1965], Wybrane pisma filozoficzne. Warsaw: PWN.

TWARDOWSKI, K. [1999], On Actions, Products and Other Topics in Philosophy, Brandl, J. and Woleński, J. (ed.). Amsterdam: Rodopi.

WOLEŃSKI, J., SIMONS, P. [1989], De veritate: Austro-Polish Contributions to the Theory of Truth from Brentano to Tarski, [in:] Szaniawski, K., (ed.), The Vienna Circle and the Lvov Warsaw School, Dordrecht: Kluwer, pp. 391-442.

ZIMMERMANN, R. [1853], Philosophische Propaedeutik für Obergymnasien. Zweite A theilung: Formale Logik für Obergymnasien. Vienna: Braumüller. $2^{\text {nd }}$, revised ed. 1860, and $3^{\text {rd }}$ ed. 1867 , Vienna: Braumüller. 